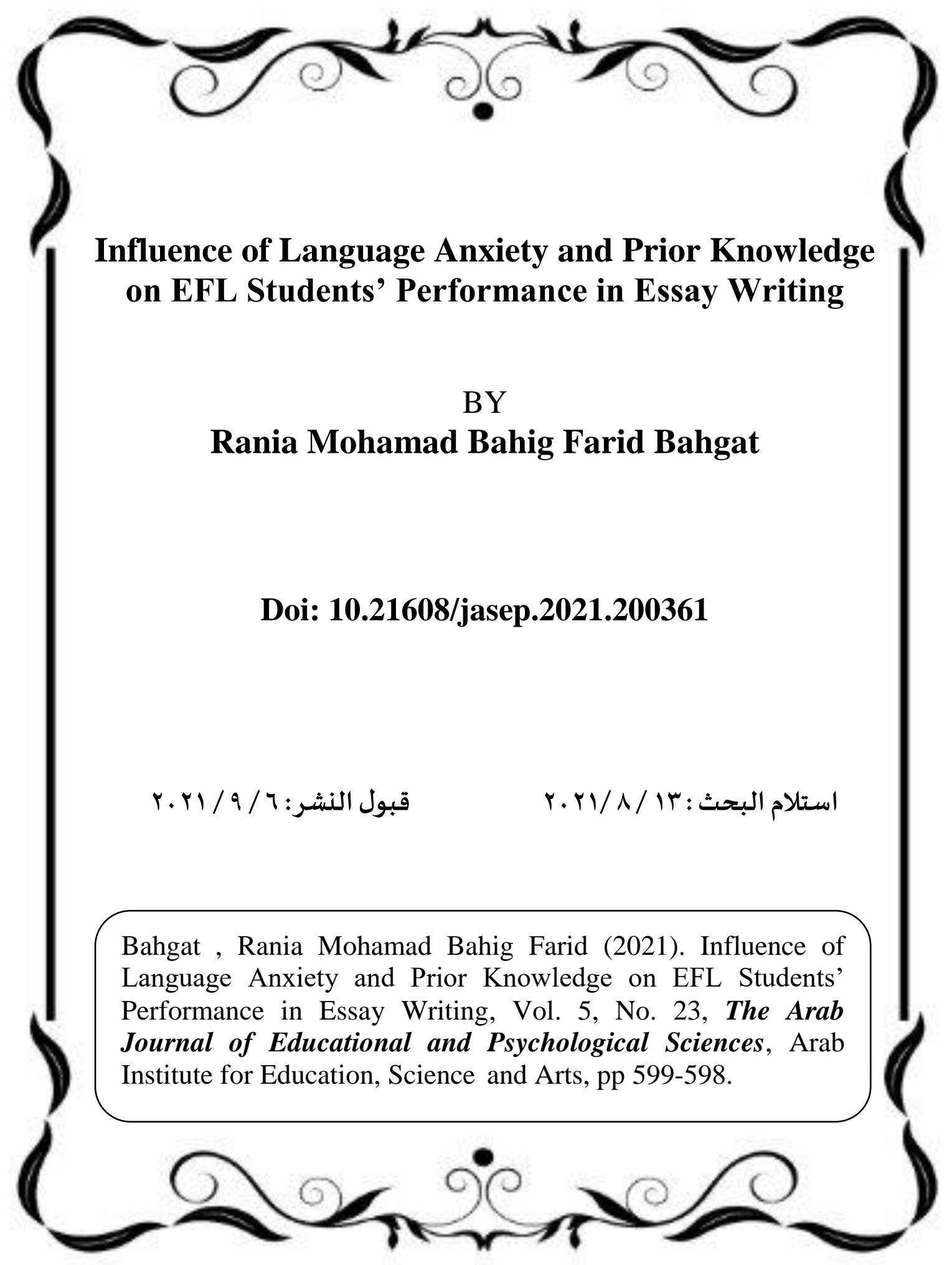




\title{
Influence of Language Anxiety and Prior Knowledge on EFL Students' Performance in Essay Writing
}

\begin{abstract}
:
Recent research efforts in teacher education have focused on innovative instructional delivery with little attention to learner-related variables such as language anxiety and prior- knowledge that can affect learning outcomes in English essay writing. Notwithstanding these interventions, the problems of mass failure and poor quality of essays still persist among EFL students majoring English language. Therefore, the current study examined the relationship between language anxiety and prior knowledge on EFL students' performance in essay writing. The research adopted a descriptive research design of survey type. Data were collected using two research instruments: Language Anxiety and Prior Knowledge Questionnaire and an Achievement Test in Expository Writing. Three hypotheses were tested at a 0.05 level of significance, and 350 students were randomly selected. The results showed that there were significant relationship between the independent variables and students' achievement in expository essay writing.
\end{abstract}

Key Words: Language Anxiety, Prior Knowledge, Essay Writing 


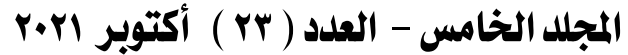

\section{المجلة العربية للعلوم التربوية والنفسية}

\section{Introduction}

Language is primarily an instrument of communication among human being in a community. Language is a means of interaction between and among people. Here, it has function as a tool which connects them in their surroundings. People realize that without language they cannot interact to each other. Language can become a bridge to connect one another that live in different places and cultures. By using a language one can gain information, knowledge, and express one's feeling, and emotions. Nowadays, many people learn the international languages. One of the international languages is English.

The importance of English language in the Egyptian educational system is underlined by the fact that the subject is taught and learned at all levels of education and evaluation of students' learning in other subject areas is largely conducted in English. One major area of concern among essay writing -in-English is the incessant poor performance of EFL students in essay writing-in-English. The poor performance of students has been attributed to conventional approach used in teaching of the subject (Maduabuchi, 2006).

Different writing tasks such as letter writing, speech and article writing, and argumentative/debate, narrative, descriptive, and expository essay types are taught and examined in EFL sessions. However, expository writing is the most demanding because it requires learners to have a grasp of both the linguistic and technical knowledge of the essay. Akinborewa \& Olagbaju (2010) describes expository essay as a form of writing that is intended to inform, enlighten, and educate the readers. Expository writings require students to transmit their ideas, opinions, and facts to the reader and they could be requested to produce an essay that is suitable for publication in a national/local magazine. In spite of the importance of English to students' success in education and academic advancement, 
many students still find the subject difficult to pass especially in the examinations (Meziobi \& Meziobi, 2014).

Writing is a complex activity since it requires students' comprehensive

abilities such as mastering grammar, vocabulary, and punctuation. Besides, to write well, the students are expected to be able to present their ideas in the written form as writing is a means of communication. However, some think that writing is not only delivering ideas to others but also using a sheer energy to complete the writing process itself: thinking the ideas, preparing the outline, transferring the outline into draft, revising the draft, and finally proofreading the draft to prepare for the final outcome. Ogunyemi \& Olagbaju (2020) state that writing is a skill that is acquired through study. Writing is one of English skills that should be taught integratedly, but it is regarded as the most difficult language skill to learn for learners. It is often perceived as the most difficult language skill since it requires a higher level of productive language control than the other skills. In fact, the students are not capable to make a good writing. The reason that they cannot make a good writing is caused by poor vocabulary, difficulty in generating their idea, poor grammar, and so on (Biggs \& Tang, 2011).

The WAEC Chief Examiners (2020, 2019) highlight students' poor understanding of the essay questions, errors in grammar, spelling, and punctuation as some of the factors responsible for poor performance in essay writing in particular and English language in general. The report concluded that teachers need to help candidates by teaching them the requirements of the different aspects of the examination, especially essay writing. This is perhaps why most of the efforts aimed at ameliorating the problem of mass failure in English language examinations in Egypt have largely been focused on teacher and instructional-related variables. Some of the previous studies have investigated the effect of teachers' questioning behavior and 


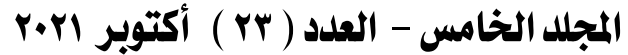

\section{المجلة العربية للعلوم التزبوية والنفسية}

instructional organization (Fakeye \& Ayeda, 2013) teachers' communication styles (Ogunyemi \& Olagbaju, 2020) and so on.

Although these studies reported the effectiveness of teacherrelated factors in improving students' achievement in different aspects or skills of the English language, performance in the subject in public examinations has not improved significantly. This is because there are several other learner related factors such as cognitive style, gender, language exposure, verbal ability, vocabulary knowledge, language anxiety, and prior knowledge that are able to influence or contribute to students' learning outcomes in EFL classroom. Success in English language examination at WAEC- and NECO-conducted examinations has been strongly tied to students' ability to succeed in the written aspect of the examination. Expository essay is a regular question type in the essay or composition section of the examination every year. Writing an expository essay presents at least two challenges to the foreign language learner: he or she must demonstrate a mastery of the rudiments of the target language and the knowhow on the technicalities of the topic to be written on.

Demonstrating a mastery of the writing skills or use of the target language can be very challenging for a foreign language learner. It is often in form of a mild or pronounced apprehension or anxiety in a second language classroom. In actual fact, several language teachers have acknowledged the existence of language-induced anxiety in second/foreign language classrooms and its influence on students' performance in the target language (Dewey, et al., 2018; William \& Andrade, 2008). Similarly, learner-centered variables such as language anxiety and prior knowledge are prevalent in most EFL classes. This is because most learners have acquired the mastery of their mother tongue before the fourth year of primary/basic education when English "progressively" becomes the language of instruction in the classroom (Federal Republic of Nigeria, 2013). 
According to (Olagbaju,2009), the implication of the Egyptian educational policy is that learners have to learn English (as a foreign language) and learn with English at the same time. Most of the learners struggle to learn English and with the English language, especially because they unassumingly transfer the rules, styles, and pronunciation of the first language (L1) to the foreign language (FL) classroom. Learners' prior knowledge in L1 is capable of creating anxiety that hinders the learning or acquisition of FL in most EFL classrooms.

In line with the aforementioned points, (Riasati, 2011) posits that second/foreign language learning experience can be demanding because of the feeling of anxiety that most ESL/EFL learners experience. Often, the second or foreign language learners encounter anxiety as a feeling of apprehension, nervousness, and pressure associated with the learning of a new language in a second or foreign language atmosphere. Reference (Dewey, et al., 2018) describes anxiety as one of the dominant psychological factors in most second language classrooms. This suggests that language anxiety can hinder or support foreign language acquisition or learning processes. In (Donkaewbua, 2016), language anxiety is a product of transfer of apprehension to language learning situations or a response to unfamiliar stimuli in the process of learning a language. Such anxieties, if unfettered, are capable of hindering the language learning process or making the experience unpleasant. Therefore, language anxiety is an implicit or explicit kind of apprehension exhibited by language learners in a foreign/second language classroom.

It is not all forms of anxiety that are bad because some anxieties can be helpful in motivating or facilitating the desired change while the harmful or negative anxiety hinders learning performance (Spielmann \& Radnofsky, 2001). It is also possible for foreign language learners' anxiety to be neutral and it has no impact on the language learning process. In view of the inconclusive nature of anxiety and its role in language learning situations, this study 


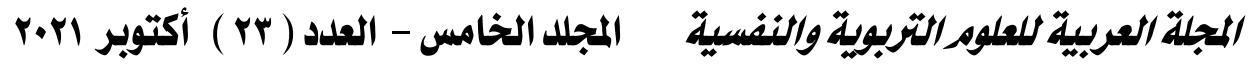

determines the influence of language anxiety on EFL students' achievement in expository essay.

One of the factors responsible for anxiety during a second/foreign language instruction is how well learners are able or not able to integrate the new instruction into their schema. That is a situation where learners do not have prior knowledge that aids in recall or transfer of learning, which serves as a platform for the new knowledge. Prior knowledge refers to the sum of relevant body of knowledge or experience possessed by learners relevant to the task they are expected to perform. Reference (Wenk, 2017) avers that prior knowledge helps students to recall and make use of what they have been taught through a complex network of interrelated information that they bring to the classroom. Prior knowledge and experiences influence the thinking of EFL learners in the language classroom and new learning experiences are often constructed based on their prior knowledge.

Similarly, prior knowledge deals with the meta-cognitive aspect of learning especially when learners need to compose or brainstorm before or during the process of writing an expository essay. There is no vacuum in the construction of knowledge because the new body of knowledge has to be built on some old understanding or prior knowledge. This is perhaps why (Jonassen \& Grabowski, 1993) submits that the higher the volume of prior knowledge an individual possesses is, the lesser the instructional support that is needed, and the lesser the prior knowledge an individual possesses is, the higher the support will be needed. The concern of this study is that the interaction between students' prior knowledge and anxiety in EFL classroom is capable of determining students' level of success irrespective of the teacher-related factors such as subject mastery, qualification, choice of instructional strategy, and the quality of corrective feedback in the classroom. Therefore, the concern of this 
study is to examine the relationship between language anxiety and prior knowledge on EFL students' achievement in expository essay.

Anderson's Schema Theory was developed mostly in the 1970s by American educational psychologist, Richard Anderson. Schema theory describes how knowledge is acquired, processed, and organized. Schema or schemata refer to a mental framework used by humans used to represent and organise information, which aids in easy recall. These schemata are building blocks of cognition derived from learners' experiences or prior knowledge and they enable us to recall, modify our behaviour, concentrate our attention on key information, or try to predict the most likely outcomes of events. Schema influences the processes involved in students' interest and ability to pay attention and absorb new knowledge: people are more likely to notice things that fit into their schema.

The theory further states that people can quickly organize new perceptions into schemata and act without effort. Schema theorists suggest that knowledge is organized through an elaborate mental activity, which involves prior knowledge, cognitive processing, and memory recall. Similarly, this study involves how psycholinguistic and cognitive factors such as language anxiety and prior knowledge contribute to students' active participation in the learning process through cognitive processing and memory recall in the process of foreign language instruction with the aid of the learners' schema. These factors enable the learners to actively participate and facilitate learning during the process of classroom instruction. EFL students often construct their learning by relying on their schema to actively generate their own learning. The theory is applicable to this study in the sense that schema-related factors such as language anxiety and prior knowledge play every important role in ESL instruction and they can be maximized to improve learning experience and learning outcomes.

Language Anxiety and Prior Knowledge as Factors in EFL Students' Learning Outcomes. 


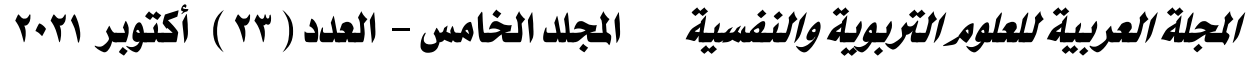

English language instruction is largely used as a foreign language in schools because most of the learners live in indigenous linguistic environment and must have acquired at least one indigenous language as a mother tongue before the official school age. When language learners have acquired the requisite skills of a language before learning a new language, several learner related factors, which include language anxiety and prior knowledge, are likely to interfere with learning outcomes and the process of instruction in EFL classrooms. Learners' anxiety is a common phenomenon during instructional procedural processes, especially if the topic, method, or teaching style is unfamiliar. Prevalence of language anxiety in a foreign language classroom is capable of affecting the teaching and learning of the four language skills, particularly the writing skill. Language anxiety in the classroom is the worry or apprehension encountered by the second or foreign language learners, which is capable of hindering effective learning of the target language. Teachers play an important role in enriching students' learning experiences and they could trigger anxiety in the foreign language classroom without taking note of it. As a factor in foreign language learning situations, it is important that language anxiety should be detected early and assistance or support should be provided for language learners in and out of the classroom.

Reference (Riasti, 2011) avers that learning a second/foreign language in a multilingual setting is an onerous task because of the apprehension displayed by most ESL/EFL learners in the process of language learning, which often makes the experience less enjoyable. The reality of overt or covert anxieties based on the learning and acquisition of the target language in ESL classrooms suggests that teachers should pay close attention to such factors. For example, (William \& Andrade, 2008) submits that several language teachers have acknowledged the existence of language anxiety in ESL/EFL classrooms and its influence on students' performance in the target language. 
According to (S,enel, 2016) and Dewey, Belnap, and Steffen (2018), language anxiety was found to hinder language learning especially in the development of the four skills and they recommended that efforts should be made to find out areas of EFL students' concerns, calm such down, and investigate the sources of their apprehensions. This can be because the process of learning is both cognitive and affective; therefore, when EFL learners approach instruction in the target language with anxiety or apprehension, effective learning cannot take place. The social aspect of language anxiety can affect ESL learners' confidence level and self-esteem when it comes to effective communication in the target language.

Ogunyemi \& Olagbajun (2020). describes language anxiety as a communication- related apprehension arising from ESL/EFL learners' inability to adequately express them, fear of negative social evaluation arises from a need to make a positive impression on others, and test anxiety arising from worry about academic achievement. There is a distinction between test apprehension and language anxiety because language anxiety is a product of nervousness in communication or fear of social evaluation while test anxiety is a general problem, which is not dependent on language anxiety. Language anxiety is a subjective variable in ESL/EFL situations and Honggand, 2019 describes it as an important factor in individual differences in second language acquisition which teachers need to pay attention to. S,enel, (2016). found the influence of language anxiety on ESL/EFL students' learning outcomes to be significant and suggested that teachers need to reduce the negative effects of anxiety in EFL classrooms.

Apart from language anxiety, prior knowledge also plays a prominent role in second language learning. Prior knowledge covers the total of the relevant skills, aptitude, and know-how that a learner possesses before coming into contact with a new body of knowledge or information. Prior knowledge aids in recall or transfer of knowledge and they can be in form of either misconceptions or 


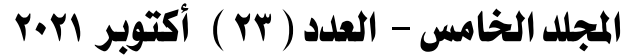

\section{المجلة العربية للعلوم التربوية والنفسية}

alternative conceptions Star, et al., (2009). Prior knowledge deals with the students' schema and the cognitive aspect of learning. In foreign language situations, for example, EFL students' prior knowledge does not exist as separate or independent threads of information but as an intricate network of interrelated previous knowledge. Therefore, students' prior knowledge can be used to enhance the quality of instruction and improve students' learning outcomes in ESL classrooms.

Jonassen \& Grabowski, (1993) submits that there is a connection between prior knowledge and instruction because learners with a high volume of prior knowledge require less instructional support. However, Jonassen \& Grabowski, (1993) statement can only be said to be true if the students' prior knowledge is supportive of the new body of knowledge. But if the prior knowledge or schema cannot accommodate the new content or instruction in the target language, ESL students would either struggle or transfer unwholesome content from the prior knowledge in their first language to the target language.

Prior knowledge can be subjective in a teaching and learning process and it is one of the factors that account for individual differences in classrooms. Prior knowledge exists in all EFL classrooms and it is capable of influencing the course of instruction and students' learning outcomes in the target language. Teachers should be conscious of students' prior knowledge so as to plan their instructions to appeal to their students' schema. Star, et al., (2009) investigated the role of prior knowledge in the development of strategy flexibility in computational estimation and found that prior knowledge impacted the development of flexibility. Similarly, Thompson and Zamboanga (2003) examined the role of prior knowledge on flexibility in the use and knowledge of strategies in mathematics. The result showed that prior knowledge, self-belief, and previous study success were positively inter-correlated with prior knowledge and previous study success showing the strongest positive 
correlation with the final grade. However, studies on the influence of language anxiety and prior knowledge on students learning outcomes have largely focused on mathematics, computer programming, and other science-related subjects with little or nothing on essay writing. Therefore, this study examines the influence of language anxiety and prior knowledge on students' learning outcomes in essay at Faculty of Education.

The ability to write essays well is one of the determinants of academic success. In many university departments both graduate and undergraduate students are required to organize ideas pertinent to a specific topic into coherent and competently written forms. Thus, the acquisition of appropriate essay writing techniques becomes essential for students, particularly when essays are part of their coursework and contribute to their final assessment. Yet, since the art of essay writing is assumed to be part of a repertoire of advanced skills students bring to university from school, extensive instruction in essay writing skills is rare at the tertiary level in New Zealand. Students are faced with a dilemma: realizing that their essay writing performance could perhaps be improved by adopting better techniques, they may be unaware of the precise means available to them of effecting improvement. They may be unsure whether their essay writing practices are adequate and which, if any, need to be changed. On the other hand, since the precise expectations of their markers are often unknown to them, and may become clearer only as more essays are written, whether due to increasing familiarity with individual markers' techniques or as the result of continued practice and self-evaluation, students stand to gain or lose marks in a relatively haphazard

\section{Statement of the Problem}

Efforts to improve students' performance in English language and essay writing in particular have largely focused on pedagogical innovations with little attention to learner-related variables such as 


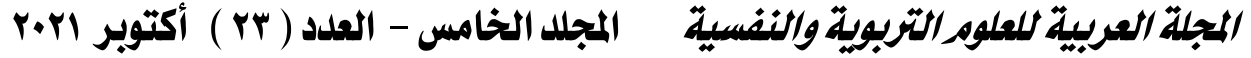

language anxiety and prior knowledge that can influence learning outcomes in ESL classrooms. In spite of these interventions, the problems of mass failure and poor quality of essays still persist. Studies have confirmed that language related anxiety and prior knowledge in ESL classroom can influence students' performance irrespective of the quality of instruction in a second/foreign language classroom. Most of the previous studies on learner-related factors in foreign language learning considered variables such as cognitive style, gender, maturation, foreign language anxiety, and vocabulary knowledge, with little emphasis on the relationship between language anxiety and prior knowledge on students' achievement in essay writing in ESL classroom. Therefore, this study determined the relationship between language anxiety and prior knowledge on achievement in expository essay writing among EFL students.

\section{Research Questions}

1- What is the effect of language anxiety on EFL student's performance in essay writing?

2- What is the effect of prior knowledge on EFL student's performance in essay writing?

\section{Hypotheses of the Study}

- There is statistically significant relative relationship between language anxiety and students' achievement in essay writing.

- There is statistically significant relative relationship between prior knowledge and students' achievement in essay writing.

\section{Method}

\section{-Research Design, Population, and Sampling Procedures.}

The research adopted a descriptive research design of survey type. The population consists of 350 in-service students at Faculty of Education. They were randomly selected for the purpose of this research.

\section{- Variables.}


The independent variables are language anxiety and prior knowledge while the dependent variable is EFL essay writing.

- Instruments and Validation Process.

Two instruments were used in this study. The first instrument, Language

Anxiety and Prior Knowledge Questionnaire (LAPKQ), was designed by the researcher. LAPKQ is a 28 -item questionnaire that has three parts: the first part requested demographic information from the participants, the second aspect on language anxiety comprises 15 items with a three-point-scoring scale of Always (3), Rarely (2), and Never (1), the third aspect is on prior knowledge and it consists of 13 items with a two-point scale of Yes (2) and No (1). For content validity, there was a pilot test using a sample of 35 students with similar characteristics but not part of population for the study. Cronbach alpha statistics was used to analyze their responses and a coefficient of 0.78 was recorded. The second instrument is Achievement Test in Essay Writing. The instrument is a standardized test.

\section{Findings of the Research}

The result (table.1) shows the relationship each of the independent variables (language anxiety and prior knowledge) had with students' achievement in essay writing. The result indicates that language anxiety had a negative significant relationship with students' achievement in essay writing $(r=-0.029 ; p>0.05)$. This implies that language anxiety influenced students' achievement in essay writing. Thee table also indicates that prior language had a significant relationship with students' achievement in essay writing $(r=-0.052$; $p>0.05)$. This also implies that students' prior language has an influence on their achievement in essay writing. Based on these results, the hypotheses that there is significant relative relationship between the independent variables (language anxiety and prior knowledge) and students' achievement in essay writing is accepted. This findings agrees with Akaraka (2015) who observed that exposing 


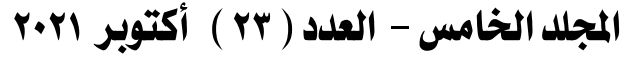

\section{المجالة العربية للعلوه الثربوية والنفسية}

students to prior to instruction can enhance learning. The result may be attributed to students' determination to achieve the set instructional objective.

Table (1). Relative relationship of independent variables with students' achievement in essay writing

\begin{tabular}{|cccc|}
\hline Variables & $\begin{array}{c}\text { Students' } \\
\text { achievement in } \\
\text { essay writing }\end{array}$ & Language anxiety & $\begin{array}{c}\text { Prior } \\
\text { Knowledge }\end{array}$ \\
\hline $\begin{array}{c}\text { Students' achievement in essay } \\
\text { writing }\end{array}$ & 1 & & \\
\hline Language Knowledge & 0.29 & 1 & 1 \\
\hline Prior Knowledge & 0.54 & 100 & 100 \\
\hline N & 100 & 22.80 & 20.60 \\
\hline Mean & 19.04 & 7.63 & 4.45 \\
\hline Standard deviation & 7.66 & & \\
\hline
\end{tabular}

\section{Discussion of the Findings}

From the foregoing, the findings of this study showed that language anxiety and prior knowledge had a significant relationship with students' achievement in essay writing. This result implies that a high level of language anxiety in the EFL classroom led to poor achievement in essay writing. The findings of this study support similar studies such as (Dewey, et al., 2018; Donkaewbua, 2016; S,enel, 2016) that found that language anxiety, if not remedied by the teacher, is capable of hindering the language learning process or making the experience unpleasant in a foreign language classroom. However, the findings of this study on language anxiety are at variance with (Spielmann \& Radnofsky ,2001) that found that students' anxiety concerning learning a concept or subject can be helpful in motivating or facilitating them to learn such concept. Also, (Horwitz, 2001) avers that anxiety can be an impetus for learning a language. The findings of this study have shown that EFL teachers need to be conscious of learning anxiety in the classroom and assist them to overcome such apprehensions in the language teaching and learning process. 
The study also found that prior knowledge had a significant relationship with students' achievement in essay writing. This result goes with (Star, et al., 2009; Thompson \& Zamboanga, 2003) that found the relationship between prior knowledge and students' achievement to be positively significant in subject areas such as mathematics and computer science.

\section{Conclusion and Recommendation}

Based on this result, the following recommendations are made:

(1) EFL teachers need to consider language anxiety more closely in the classroom and remedy such apprehensions through quality instructional delivery.

(2) Teaching English in EFL classroom should be highly interactive and communication-based, and corrective feedback must be detailed and prompt.

(3) The primary responsibility of language teachers should be to create a connection between students' schema and the new body of knowledge.

(4) EFL teachers should begin to focus more on prevailing learnerrelated variables within the classroom such as language anxiety, prior knowledge, verbal ability, and vocabulary knowledge that can influence students' achievement irrespective of the quality of the instruction that they received in the classroom.

(5)This study has revealed that the prior knowledge enhanced students' achievement in essay writing. In this regard, teachers can adopt this teaching learning strategy to achieve the same purpose. 


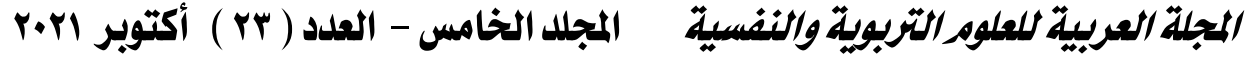

\section{References}

- D. H. Jonassen and B. L. Grabowski, Handbook of Individual Differences, Learning and Instruction, Lawrence Erlbaum Associates, Inc, Mahwah, NJ, USA, 1993.

- D. O. Fakeye and E. Ayede, "Teachers' questioning behaviour and instructional organisation as correlates of students' achievement in english language," Global Journal of Human Social Sciences Linguistics \& Education, vol. 13, no. 2, pp. 13-22, 2013.

- K. William and M. Andrade, "Foreign language learning anxiety in Japanese EFL university classes: causes, coping and locus of control," Electronic Journal of Foreign Language Teaching, vol. 5, no. 2, pp. 181-191, 2008.

- L. Wenk, !e Importance of Engaging Prior Knowledge, Hampshire College Center for Teaching and Training, Amherst, MA, USA, 2017.

- Olagbaju O. O. and Jimoh N. O., "Language exposure and subject familiarity as correlates of senior secondary school students' achievement in narrative writing," Technium Social Sciences Journal, vol. 7, no. 1, pp. 98-106, 2020.

- D. P. Dewey, R. K. Belnap, and P. Steffen, “Anxiety: stress, foreign language classroom anxiety, and enjoyment during study abroad in Amman, Jordan," Annual Review of Applied Linguistics, Cambridge University Press, vol. 38, pp. 140-161, , Cambridge, UK, 2018.

- E. Horwitz, "Language anxiety and achievement," Annual Review of Applied Linguistics, Cambridge University Press, vol. 21, pp. 112126, , Cambridge, UK, 2001.

- E. S, enel, "Foreign language anxiety of students studying English language and literature: a sample from Turkey," Educational Research and Reviews, vol. 11, no. 6, pp. 219-228, 2016.

- Federal Republic of Nigeria, National Policy on Education (Revised), NERDC Press, Abuja, Nigeria, 2013. 
- G. Spielmann and M. L. Radnofsky, "Learning language under tension: new directions from a qualitative study," !e Modern Language Journal, vol. 85, no. 2, pp. 259-278, 2001.

- K. O. Ogunyemi and O. O. Olagbaju, "Effects of assertive and aggressive communication styles on students' self-esteem and achievement in english language," Cross-Cultural Communication, vol. 16, no. 1, pp. 96-101, 2020.

- L. Honggand, "New insights into language anxiety: theory, research and educational implications," ELT Journal, vol. 73, no. 1, pp. 105107, 2019.

- M. J. Riasati, "Language learning anxiety from EFL learners' perspective," Middle-East Journal of Scientific Research, vol. 7, no. 6, pp. 907-914, 2011.

- Meziobi, K. A, and Meziobi, K. C. (2014). Teacher Education Curriculum and Teaching at the tertiary Education level in Nigeria. In U.M. Ivowi (ed) Curriculum and teaching in Nigeria Lagos: Foremost Educational Services Ltd.

- O. O. Olagbaju, !e Challenges of Using Nigerian Languages in Modern Education, University of Ibadan, Ibadan, Nigeria, 2009.

- R. A. *ompson and B. L. Zamboanga, "Prior knowledge and its relevance to student achievement in introduction to psychology," Teaching of Psychology, vol. 30, no. 2, pp. 96-101, 2003.

- R. Star, B. Rittle-Johnson, K. Lynch, and N. Perova, "The role of prior knowledge in the development of strategy flexibility: the case of computational estimation," ZDM-International Journal of Mathematics Education, vol. 41, no. 5, pp. 569-579, 2009.

- S. Donkaewbua, "Developing an anxiety in vocabulary learning through listening scale," International Journal of Language and Linguistics, vol. 3, no. 6, pp. 60-71, 2016.

- T. Akinborewa and O. O. Olagbaju, Simplified Composition Workbook, Joytal Printing Press, Ibadan, Nigeria, 2010. 


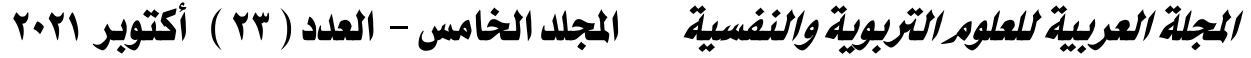

- West African Examination Council, "English language: WAEC highlights candidates' weaknesses in WASSCE exams," Daily Independent, 2020.

- West African Examinations Council, Chief Examiners' Report for the West African Senior School Certificate Examination (WASSCE), WAEC Press, Lagos, Nigeria, 2019.

- Biggs, J; and Tang, C. (2011). Teaching for quality learning at university. England: Open university Press.

- Maduabuchi, C.H. (2006). Effects of Literature Circles and collaborative learning strategies on students' comprehension of poetry. Ebonyi State University Journal of Education. 4(2), 184194. 